\title{
THE DISJUNCT COASTAL PLAIN FLORA IN THE GREAT LAKES REGION
}

\author{
A. A. Reznicek \\ University of Michigan Herbarium, North University Building, Ann Arbor, Michigan 48109, USA
}

\begin{abstract}
Three areas in the Great Lakes region are known to harbor species whose primary range is the coastal plain: (1) the southeastern Georgian Bay region of Ontario, (2) the sandplains near Lake Michigan in southwestern Michigan and northern Indiana, and (3) the lacustrine sand deposits in central and northern Wisconsin. Secondary areas with smaller concentrations are found in the southeastern Lake Ontario region of New York, the Lake Erie region, small areas of north-central Illinois, and local areas of northern Michigan. These areas are all sand deposits associated with postglacial lakes and drainage channels. A review of the flora of the Great Lakes region disclosed a list of 62 primarily coastal plain species that are disjunct to the Great Lakes region.
\end{abstract}

The species are largely herbs, nearly half are graminoids, and many are annuals. Their habitats are primarily sandy, gravelly, or peaty emergent shores of shallow, soft-water ponds and small lakes with fluctuating water levels, or sometimes sandy, periodically flooded swales. A few species are aquatic, and fewer still are bog or wet forest species. Most are evident only during years of low water levels, and sometimes their appearance is quite sporadic, making survey and monitoring work difficult. However, the consequences of loss of populations can be severe since, with disjuncts, there may be no seed source nearby to facilitate recolonization of sites. The sandy lakeshore habitats are frequently prime recreational lands, thus creating additional pressures.

Previous hypotheses for the occurrence of these disiuncts suggested gradual migration along the shores of postglacial lakes and drainages. However, these species do not typically inhabit shores of rivers and large lakes. As well, habitats along these shores undoubtedly were not continuous. Nevertheless, the localized occurrence of the species at the termini of major postglacial drainages in spite of the more widespread availability of apparently suitable habitats argues against random long distance dispersal. Here proposed is that these species migrated into the Great Lakes region through dispersal jumps of varying distances between substantial areas of suitable habitat created along major postglacial drainage channels. Once in the Great Lakes area, they were most successful in areas with extensive drying shorelines.

Keywords: Great Lakes, coastal plain, vascular plants, phytogeography, distribution.

\section{INTRODUCTION}

The occurrence of species disjunct in the Great Lakes region from their primary ranges on the Atlantic and Gulf coastal plain has been known for a long time (Cain, 1944). The first extensive treatment of these species was Peattie's (1922) classic paper on the Atlantic Coastal plain element in the flora of the Great Lakes. Earlier discussions of disjunct coastal plain species in the Great Lakes region, such as those of Harper (1905), were hampered by the fact that distributions were too poorly known at that time to permit substantive conclusions.

Since Peattie's time, three main areas in the Great Lakes region have been documented as having concentrations of species of coastal plain affinity. These areas are the extensive sand deposits associated with postglacial stages of Lake Michigan in northwestern Indiana and southwestern Michigan (Peattie, 1922, 1930; Parker, 1936; Deam, 1940); the sandy shores of the numerous lakes on the southern Canadian Shield just east of southern Georgian Bay, Ontario (Reznicek \& Whiting, 1976; Keddy, 1981, Keddy \& Reznicek, 1982; Keddy \& Sharp, 1989); and certain areas of lacustrine sand deposits in central and northern Wisconsin (McLaughlin, 1932: Tans, 1983). There has, however, been no comprehensive overview since Peattie (1922). This review aims to summarize distributional data to produce an up-to-date view of the areas of occurrence for these species in the Great Lakes region, to produce an updated list of coastal plain species in the Great Lakes region, to evaluate Peattie's (1922) phytogeographical hypotheses about the origin of this floristic element in light of modern information, and to comment on the conservation problems unique to these species.

Nomenclature follows Voss $(1972,1985)$ and Gleason and Cronquist (1991).

Much of the literature on the occurrence of coastal plain species in the Great Lakes region is concerned with species regarded as having 'coastal plain affinity'. In order both to be more precise and to restrict the number of species to a manageable figure, the discussions here will be concerned primarily with those species whose occurrence in the Great Lakes region is disjunct (typically by at least $100 \mathrm{~km}$ ) and whose main range is largely confined to the coastal plain or, if somewhat more widespread, essentially completely occupies the coastal plain. The only exception is the inclusion of 
primarily northeastern species that are disjunct to the Great Lakes region and which occur in the same habitats as the other disjuncts. Maritime strand and dune species such as Ammophila breviligulata, Cakile edentula, and Euphorbia polygonifolia are excluded as they occur in quite different habitats. These restrictions blunt some of the still valid criticisms of Fernald (1942) that people were defining coastal plain species much too broadly.

However, restricting the list to species with disjunctions conceals the information that a substantial number of species in glaciated eastern North America apparently do have the coastal plain as their immediate area of origin. This includes such prominent species as Decodon verticillatus, Drosera intermedia, Sarracenia purpurea, Woodwardia virginica, Cladium mariscoides, and several Utricularia spp. These species certainly have 'coastal plain affinities' but their occurrence in the Great Lakes region is not a disjunction.

Sources of data are cited in the figure legends with herbarium acronyms following Holmgren et al. (1990).

\section{DISTRIBUTION}

\section{Distribution within the Great Lakes region}

Mapping coastal plain disjunct species within the Great Lakes region clearly shows their occurrence in the three major areas noted in the Introduction, as documented by numerous authors. A cumulative map of the Great Lakes distribution of 12 disjuncts (Fig. 1), selected to represent both widespread and local species, also shows occurrences in four additional, minor areas. These are, from west to east, central and north-central Illinois, northern Michigan, both in the northernmost lower peninsula and the upper peninsula; especially areas adjacent to western Lake Erie and Lake St Clair, extending north even to southernmost Lake Huron; and an area southwest and south of the east end of Lake Ontario in New York State. No species occurs in all major and minor areas, although the most widespread disjuncts, such as Xyris torta (Fig. 1) and Rhexia virginica (see Fig. 4) are found in most. Typically, species found in more than one area are frequent, or at least widespread, in one area and very rare in the others. This is exemplified by the distribution of Psilocarya scirpoides (Fig. 2), which is widespread in southwestern Michigan and adjacent northern Indiana, but very scarce and local in Wisconsin, southeastern Michigan, the western Lake Erie and Lake St Clair region, and in northern Michigan. Rhynchospora macrostachya (Fig. 3), is much more restricted, being widespread in southwestern Michigan and adjacent northern Indiana, but occurring elsewhere in the Great Lakes region only rarely in the Lake Ontario region of New York.

By far the most species rich of the areas in the Great Lakes region is southwestern Michigan and adjacent northern Indiana, where the vast majority of the species occur, 51 out of the 62 species considered here. Within this large region, coastal plain disjuncts are not uniformly distributed. There are several concentrations discernable on Fig. 1, notably in Muskegon County,

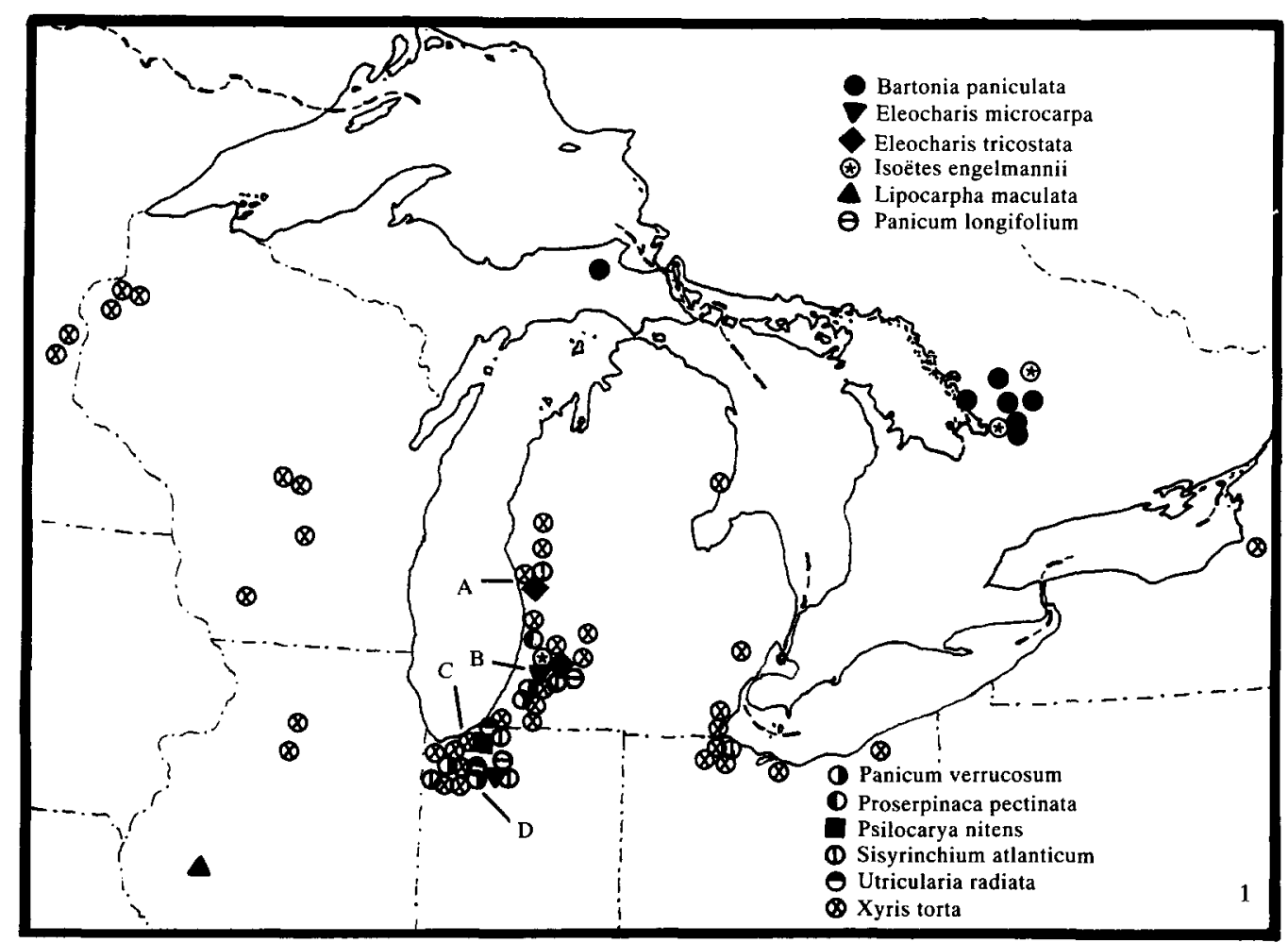

Fig. 1. Combined distribution of twelve coastal plain disjuncts in the Great Lakes region. Dots have been spaced to avoid overlap, so positions are not precise. Based on specimens in $\mathrm{MICH}$, plus additional records as follows: Bartonia paniculata (Reznicek \& Whiting, 1976, D.F. Brunton, pers. comm.); Lipocarpha maculata (Winterringer, 1959); Panicum longifolium, $P$. verrucosum, Sisyrinchium atlanticum, Utricularia radiata (Swink \& Wilhelm, 1979); Xyris torta, (Fassett, 1932; Kral, 1966; Voss, 1972; Swink \& Wilhelm, 1979; McCance \& Burns, 1984; Coffin \& Pfannmuller, 1988) 


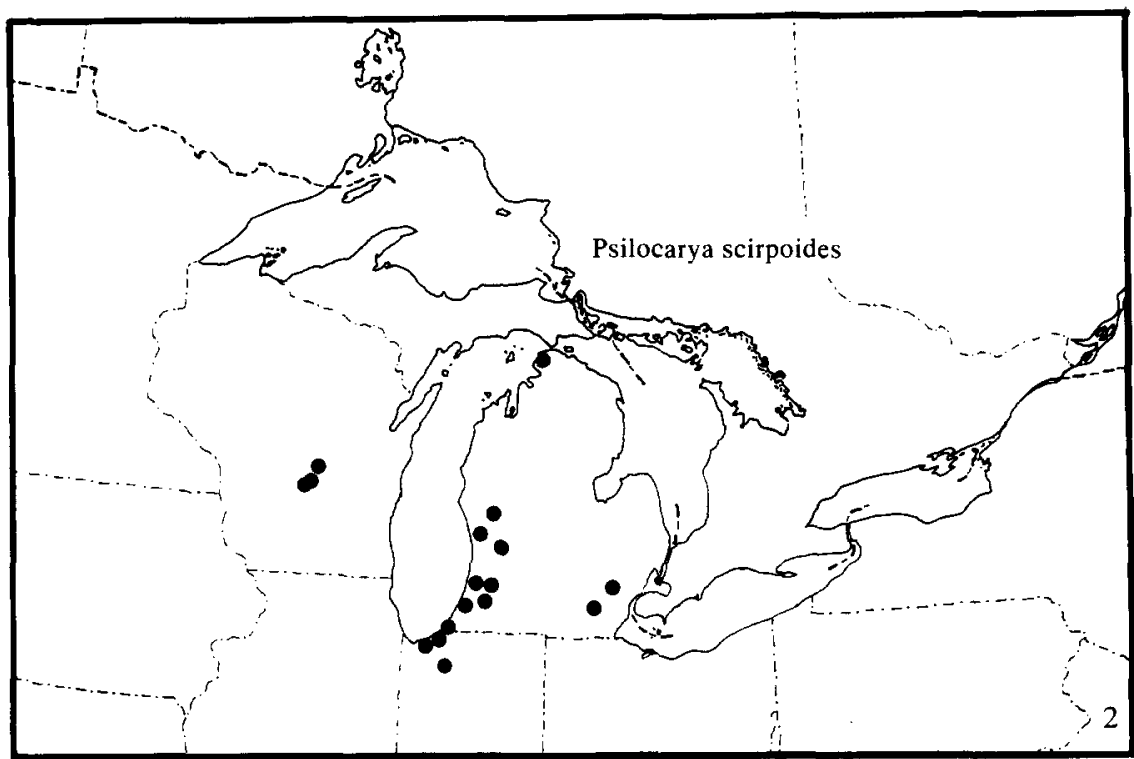

Fig. 2. Great Lakes region distribution of Psilocarya scirpoides. Based on specimens in MICH and WIS and records in Swink and Wilhelm (1979) and Voss (1972).

Michigan (A), Allegan County, Michigan (B), the Indiana Dunes region, Indiana (C), and the vicinity of the Jasper-Pulaski State Game Area, Indiana (D). These subregions are characterized by concentrations of ponds, lakes, or swales, often more or less interconnected. The southeastern Georgian Bay region, Wisconsin, and the Lake Erie-Lake St Clair region are the next richest, with 14,17 , and 24 species, respectively. Of these, the Lake Erie-Lake St Clair region is the largest, but species are very scattered within it. A very few species are scattered along the northeast shore of Lake Erie in Ontario and adjacent New York (Reznicek \& Catling, 1984), a number occur in the northeastern counties of Ohio, and a few are found in the Oak Openings of Ohio (Easterly, 1979) and in similar terrain north even to the south shore of Lake Huron. Nowhere do major concentrations occur, and for this reason the area is not considered among major centers of occurrence of coastal plain disjuncts. The remaining three minor areas, the southern and southeastern shore of Lake Ontario in New York, northcentral Illinois, and northern Michigan, have 11, 12, and 12 species, respectively.

\section{Overall distribution}

The entire ranges of these disjuncts can be divided into three somewhat arbitrary groups, as already noted above: (1) species that are more or less widespread in the eastern and southeastern United States, but with a major portion of their range on the coastal plain; (2) species essentially confined to the coastal plain, with only a few extralimital occurrences besides the disjunct colonies in the Great Lakes region; and (3) species that are primarily eastern and northern in range, usually occurring no farther south than Virginia, but ranging north into Maritime Canada. Distributions of selected

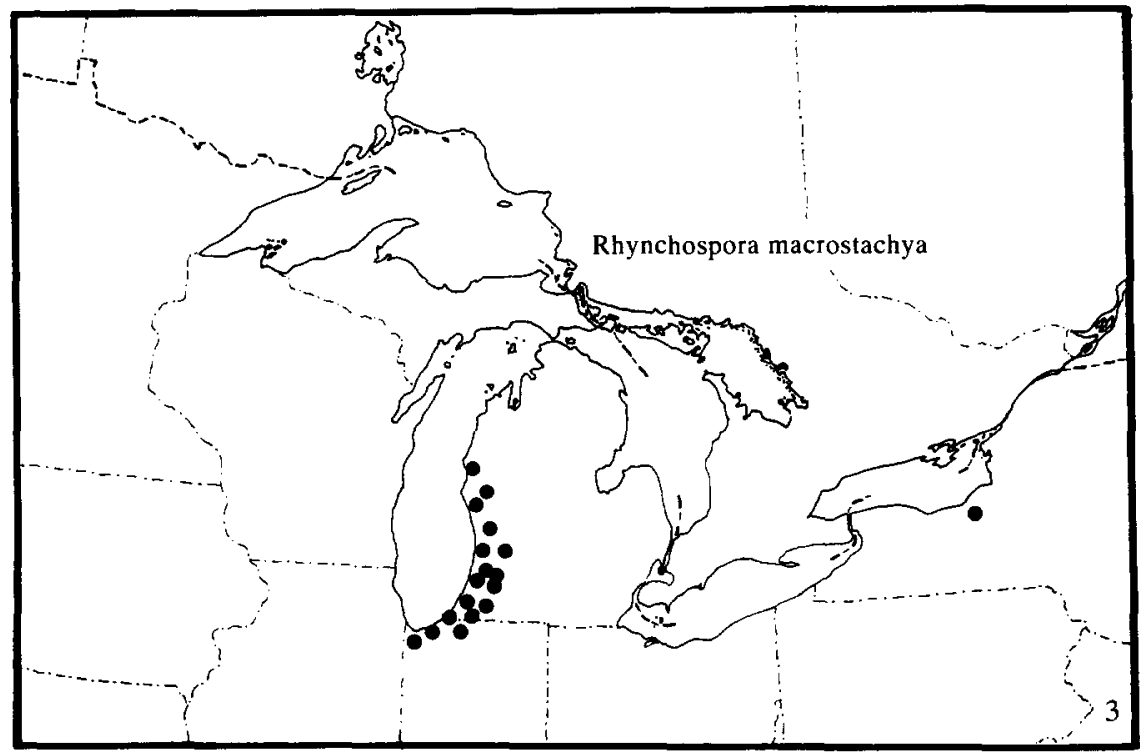

Fig. 3. Great Lakes region distribution of Rhynchospora macrostachya. Based on specimens in MICH and records in Fernald (1937), Swink and Wilhelm (1979), and Voss (1972). 


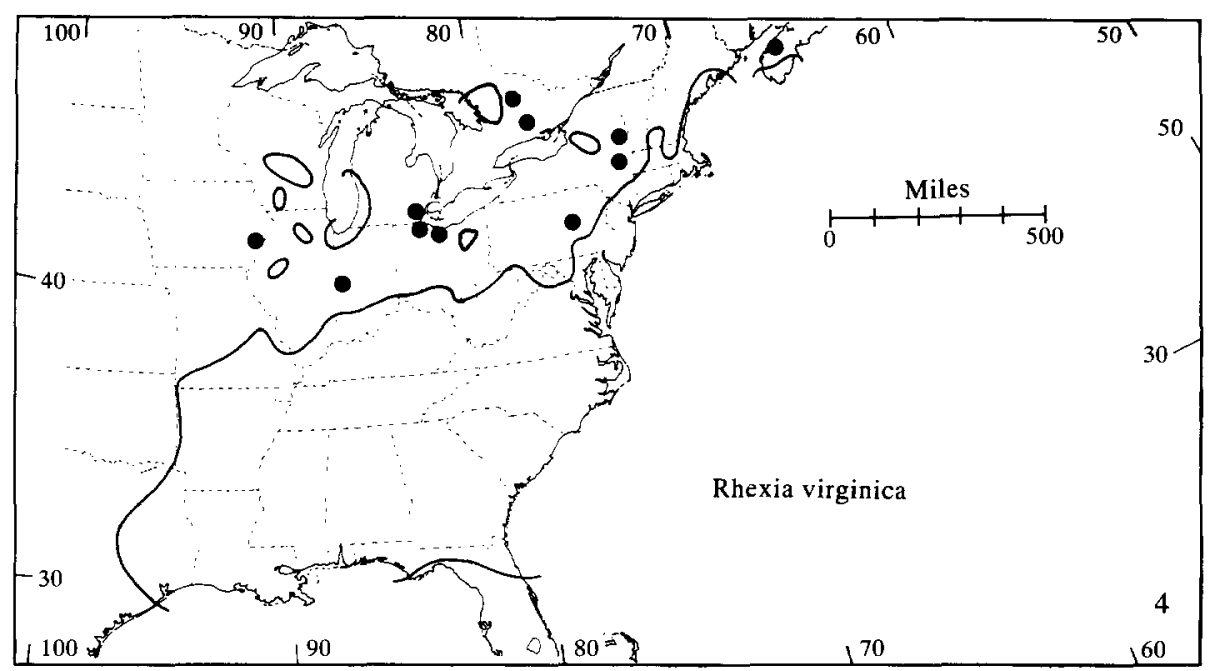

Fig. 4. Distribution of Rhexia virginica. Based on Kral and Bostick (1969), supplemented by specimens in MICH and WIS and records in Deam (1940), New York Flora Association (1990), Roland and Smith (1969), Sharp and Keddy (1983).

species of all three groups for which sufficient distributional data were available are shown in Figs 4-14. These maps demarcate the more or less continuous distributions of species with solid outlines, and disjunct portions with isolated outlines if two or more populations are represented and solid dots if only one population is represented.

Figure 4 shows the distribution of perhaps the most widespread of the species considered here, Rhexia virginica. This Rhexia also clearly shows all the major and several of the minor centers of occurrence of coastal plain disjuncts in the Great Lakes region. Figure 5 shows the distribution of Rhexia mariana, also a widespread species, although more southern in overall distribution, that is restricted in the Great Lakes region to two small regions. Half of all the disjuncts, 31 out of 62 , fall into the widespread category.

Eleocharis melanocarpa (Fig. 6) shows the classic view of the overall distribution of coastal plain disjuncts, i.e. it has a restricted coastal plain distribution, ranging from New England south to Florida and then west to Texas, with occurrences in the Great Lakes region. Peattie (1922) also mapped this species as an archetype of the coastal plain disjunct distribution. As expected, however, such clear-cut distributions are rare. The distributions of Fuirena pumila (Fig. 7), Panicum spretum (Fig. 8), and Echinodorus parvulus (Fig. 9) are similar to that of Eleocharis melanocarpa, but show varying numbers and degrees of scatter of stations off the coastal plain. However, Echinodorus parvulus admittedly is so uncommon even on the coastal plain that its distribution is difficult to categorize. The distributions of Scleria reticularis (Fig. 10) and Xyris difformis (Fig. $11)$, both of which reappear in a number of widely separated areas, especially suggest a continuum with widespread species, since a slightly denser distribution off the coastal plain in the southeast would shift them into that category. The distribution of Lycopus amplectens (Fig. 12) is especially interesting, since it is found in the Great Lakes region in northwestern Indiana and in north-central Illinois, both in the Mississippi drainage, while being essentially absent from the Gulf coastal plain. Such restricted species constitute 20 of 62 species.

Northern species are the smallest group of disjuncts, with 11 of 62 species. Example distributions are pre-

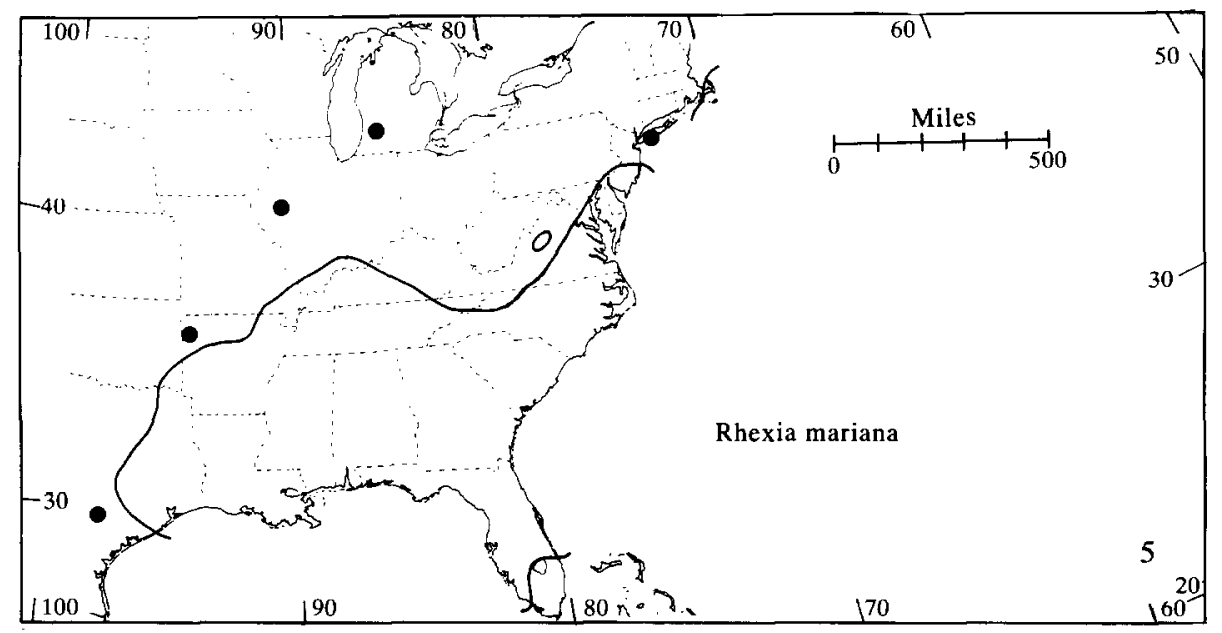

Fig. 5. Distribution of Rhexia mariana var. mariana. Based on Kral and Bostick (1969), supplemented by specimens in MICH and records in Mohlenbrock and Ladd (1978). 


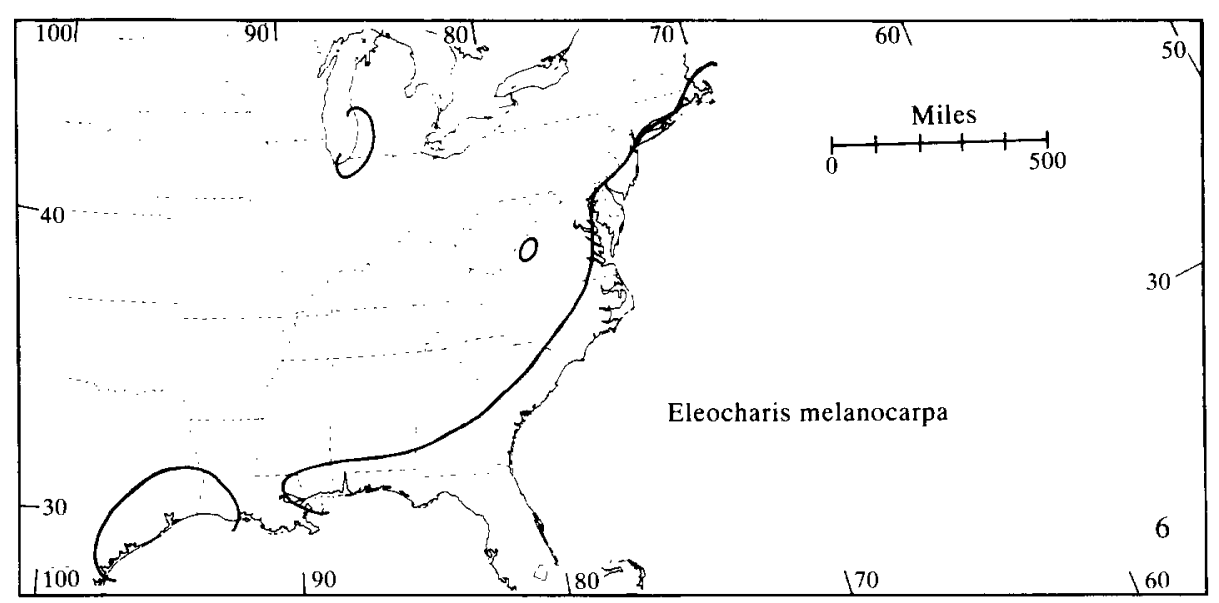

Fig. 6. Distribution of Eleocharis melanocarpa. Based on Svenson (1937), supplemented by specimens in MICH and records in Harvill et al. (1986), and Radford et al. (1964).

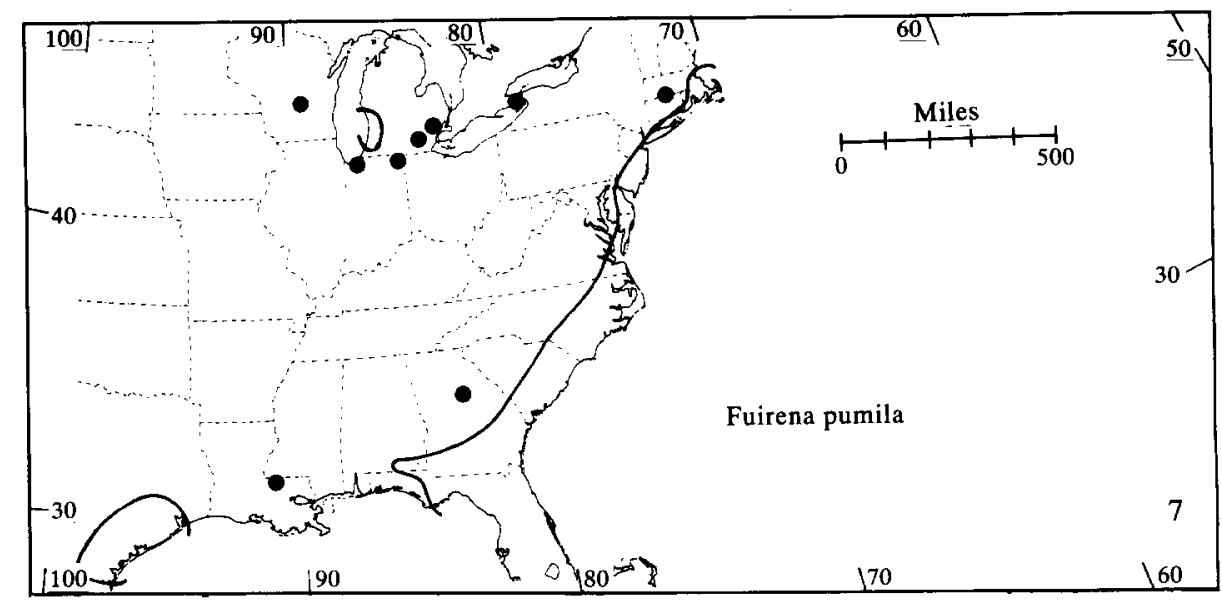

Fig. 7. Distribution of Fuirena pumila. Based on Kral (1978), supplemented by specimens in MICH and WIS and records in Jones and Coile (1988).

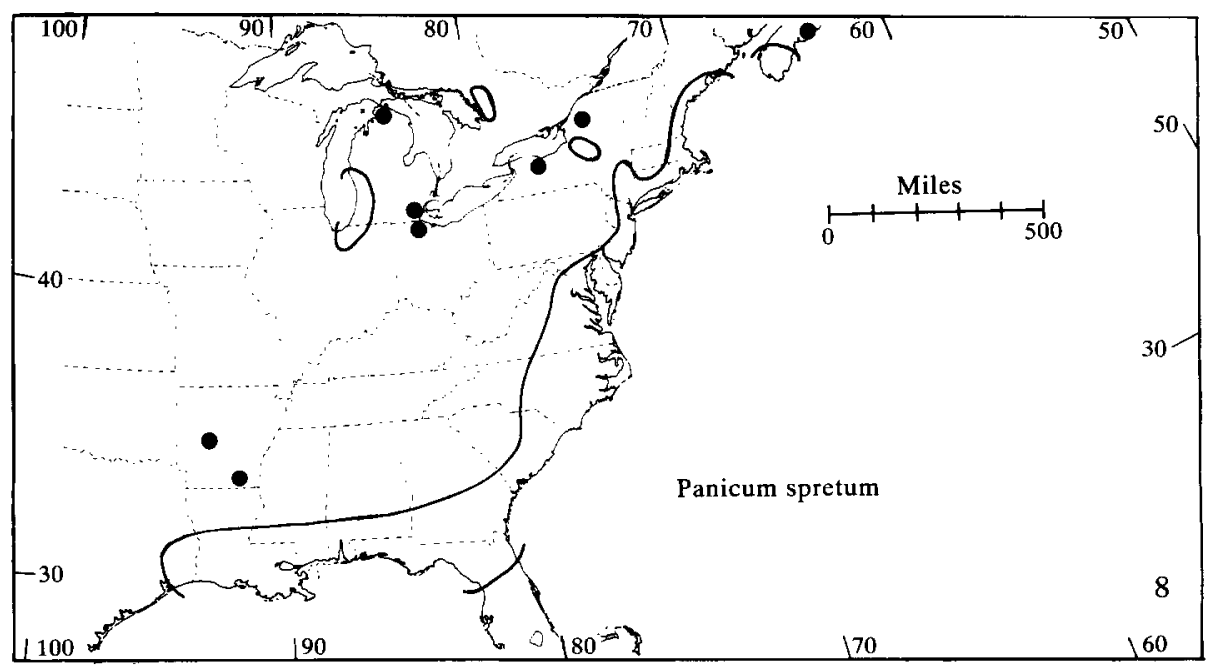

Fig. 8. Distribution of Panicum spretum. Based on Reznicek (1984), supplemented by specimens in MICH plus data from R. Kral (pers. comm.). 


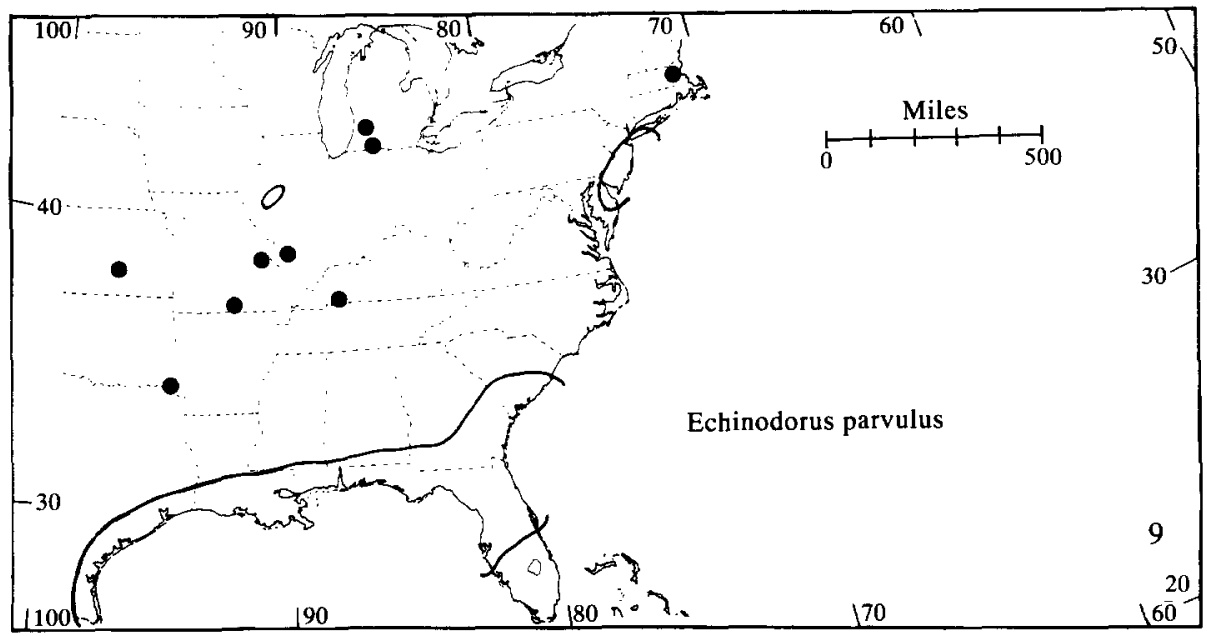

Fig. 9. North American distribution of Echinodorus parvulus. Based on Fassett (1955), supplemented by specimens in MICH and records in Mohlenbrock and Ladd (1978), and Steyermark (1963) plus data from R. Kral (pers. comm.).

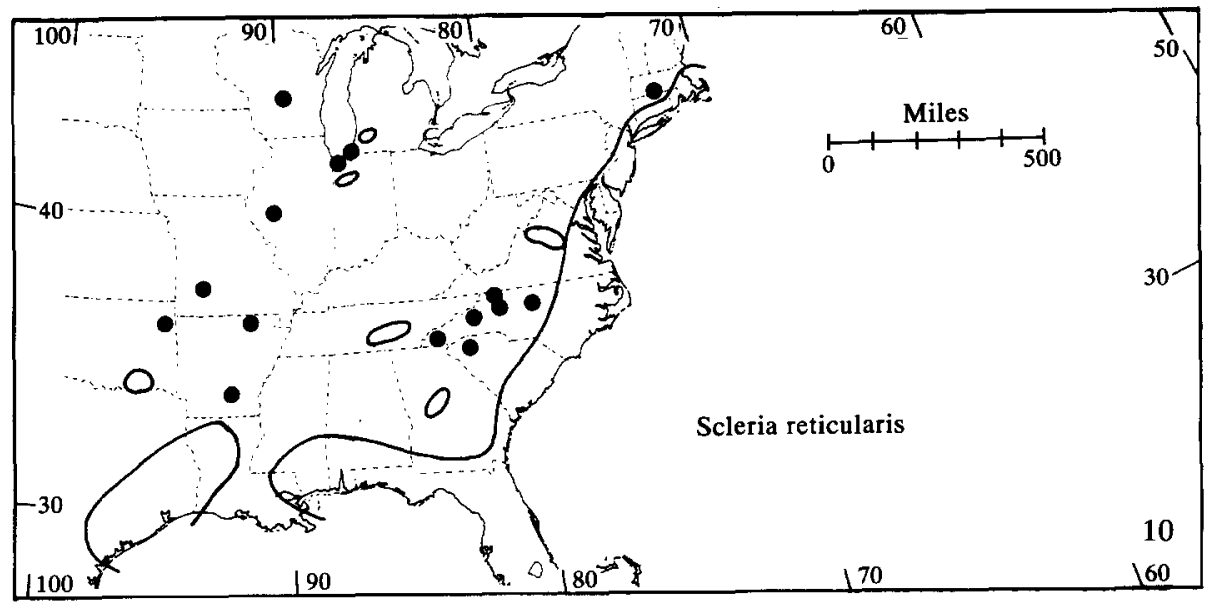

Fig. 10. North American distribution of Scleria reticularis. Based on specimens in MICH and WIS, supplemented by records in Fairey (1967), Harvill et al. (1986), Mohlenbrock and Ladd (1978), Orzell and Bridges (1987), Radford et al. (1964), Seymour (1969), and Wherry et al. (1979) plus data from R. Kral (pers. comm.).

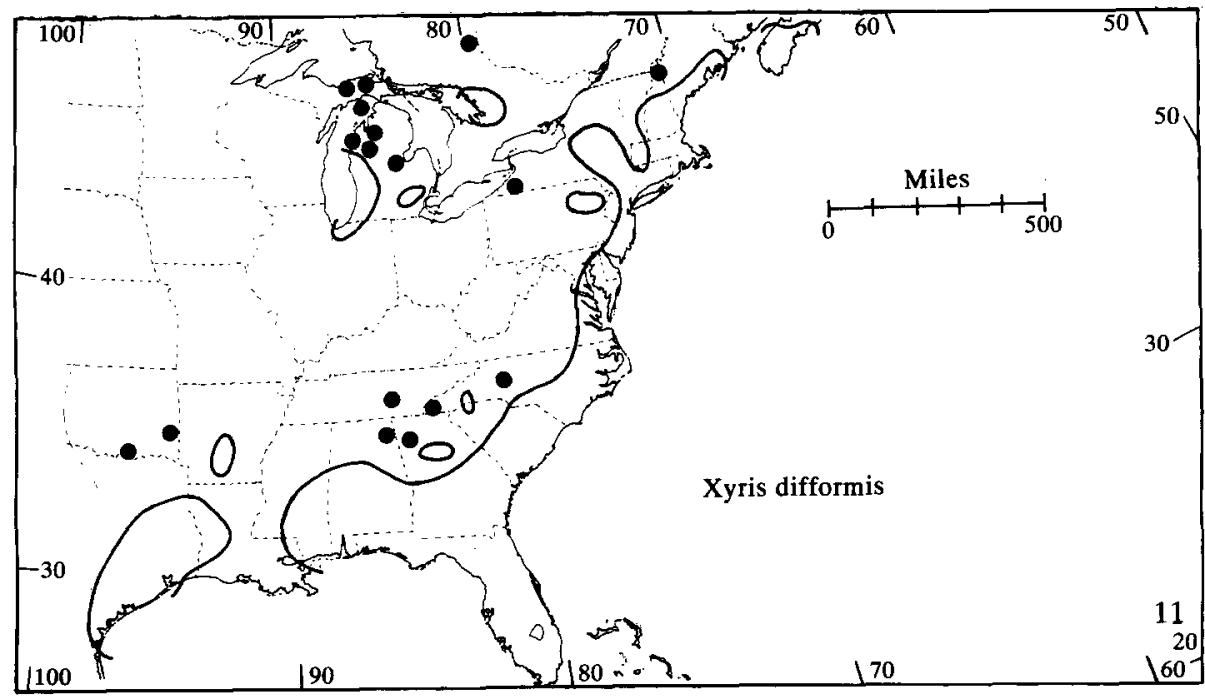

Fig. 11. Distribution of Xyris difformis. Based on Kral (1966), supplemented by specimens in MICH and records in Hellquist and Crow (1982), New York Flora Association (1990), Randall and Keddy (1983), Roland and Smith (1969), and Smith (1988). 


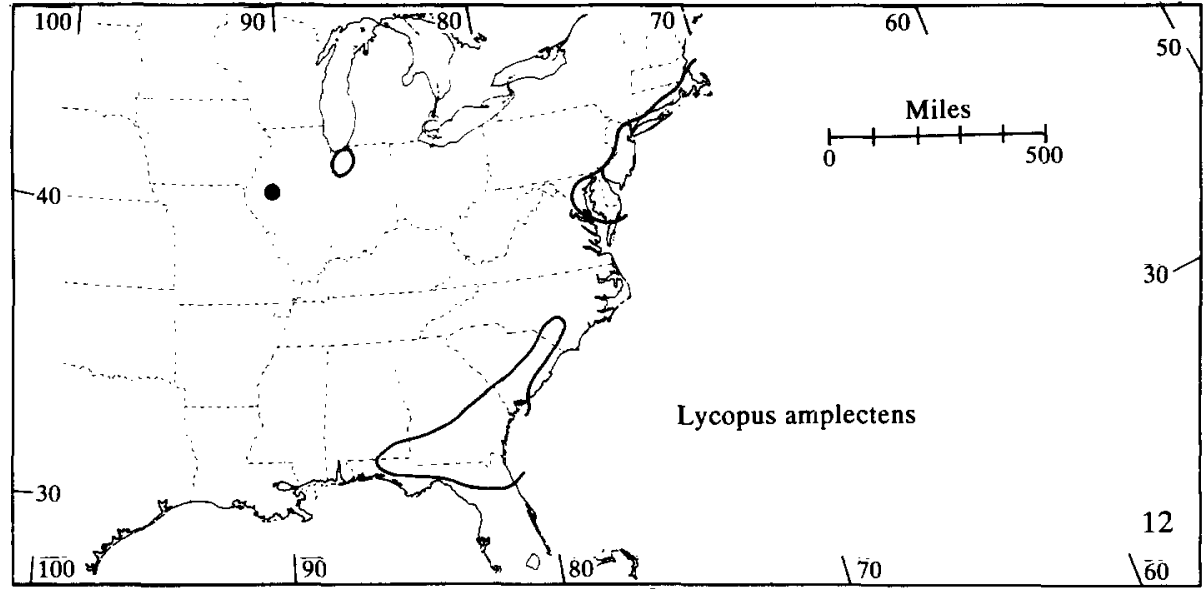

Fig. 12. Distribution of Lycopus amplectens. Based on Henderson (1962), supplemented by specimens in MICH and records in Mohlenbrock and Ladd (1978).

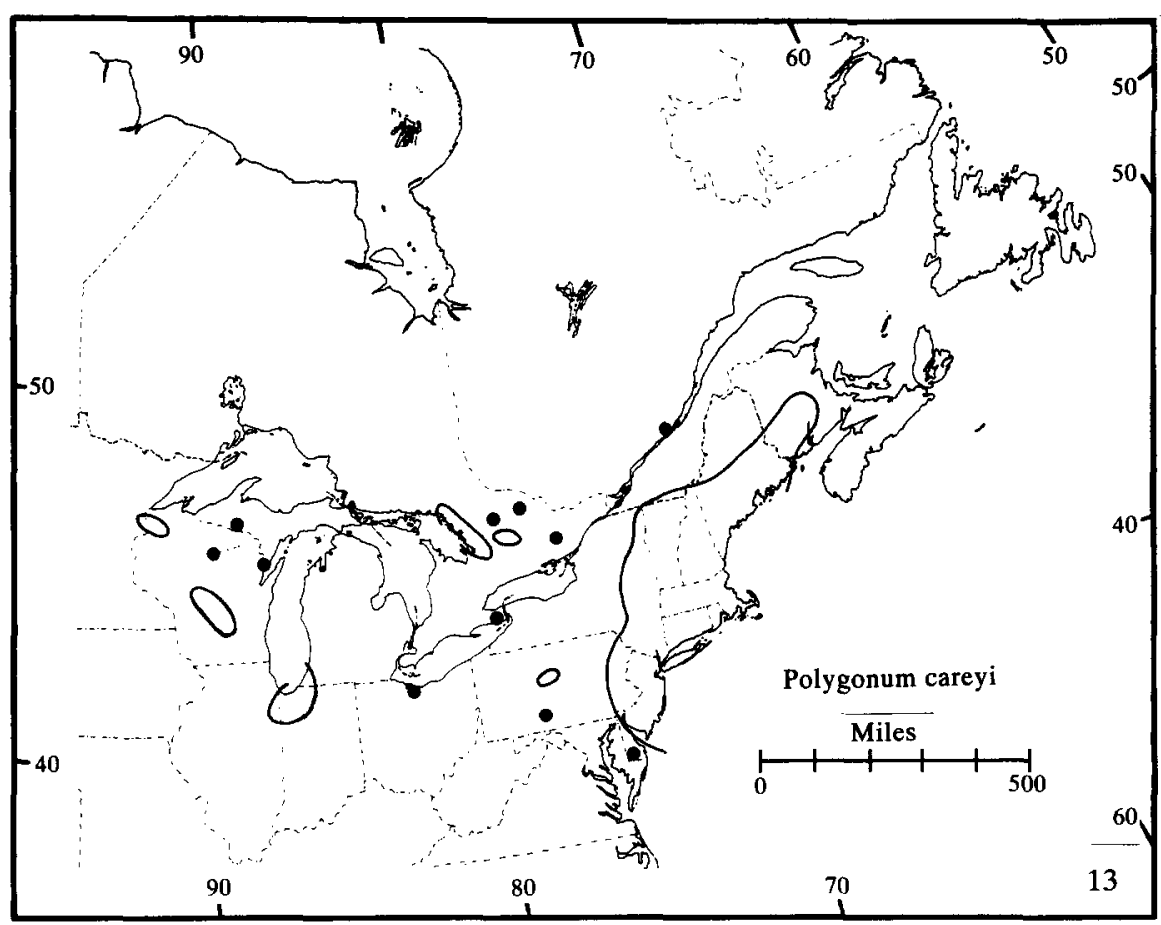

Fig. 13. Distribution of Polygonum careyi. Based on specimens in $\mathrm{MICH}$ and WIS, supplemented by records in Coffin and Pfannmuller (1988), Hinds (1986), New York Flora Association (1990), Pryer (1987), Swink and Wilhelm (1979), Wherry et al. (1979), plus data from D.F. Brunton.

sented in Fig. 13 for Polygonum careyi and Fig. 14 for Potamogeton bicupulatus. As expected, and clearly evident from the maps, northern species tend to be more widespread, especially in the northern Great Lakes region, than species in the other two categories. Northern species appear to be absent from north- central Illinois.

\section{LIST OF SPECIES}

Table 1 presents the list of species considered here, organized by the areas of occurrence within the Great Lakes region mentioned above, including the four secondary ones. The species are also classified as to whether their overall distribution is widespread and southern $(\mathrm{W})$, essentially restricted to the coastal plain $(\mathrm{R})$, or northern $(\mathrm{N})$, as defined in the preceding section. Species that occur south of the United States were included if their United States distribution followed one of the above patterns.

Decisions about the inclusion of species on this list were difficult in some instances, because the distributions of widespread southern and eastern species disjunct to the Great Lakes region and the distributions of primarily eastern species that range far inland in glaciated territory form a continuum. Thus, species like Carex atlantica subsp. capillacea, C. seorsa, Eleocharis robbinsii, Juncus pelocarpus, Listera australis, Panicum commonsianum, $P$. rigidulum, Platanthera blephariglottis, P. ciliaris, Sabatia angularis, Triadenum virginicum, Utricularia purpurea, $U$. resupinata, and Woodwardia virginica were excluded because their distributions are essentially continuous to the Great Lakes region, although within 


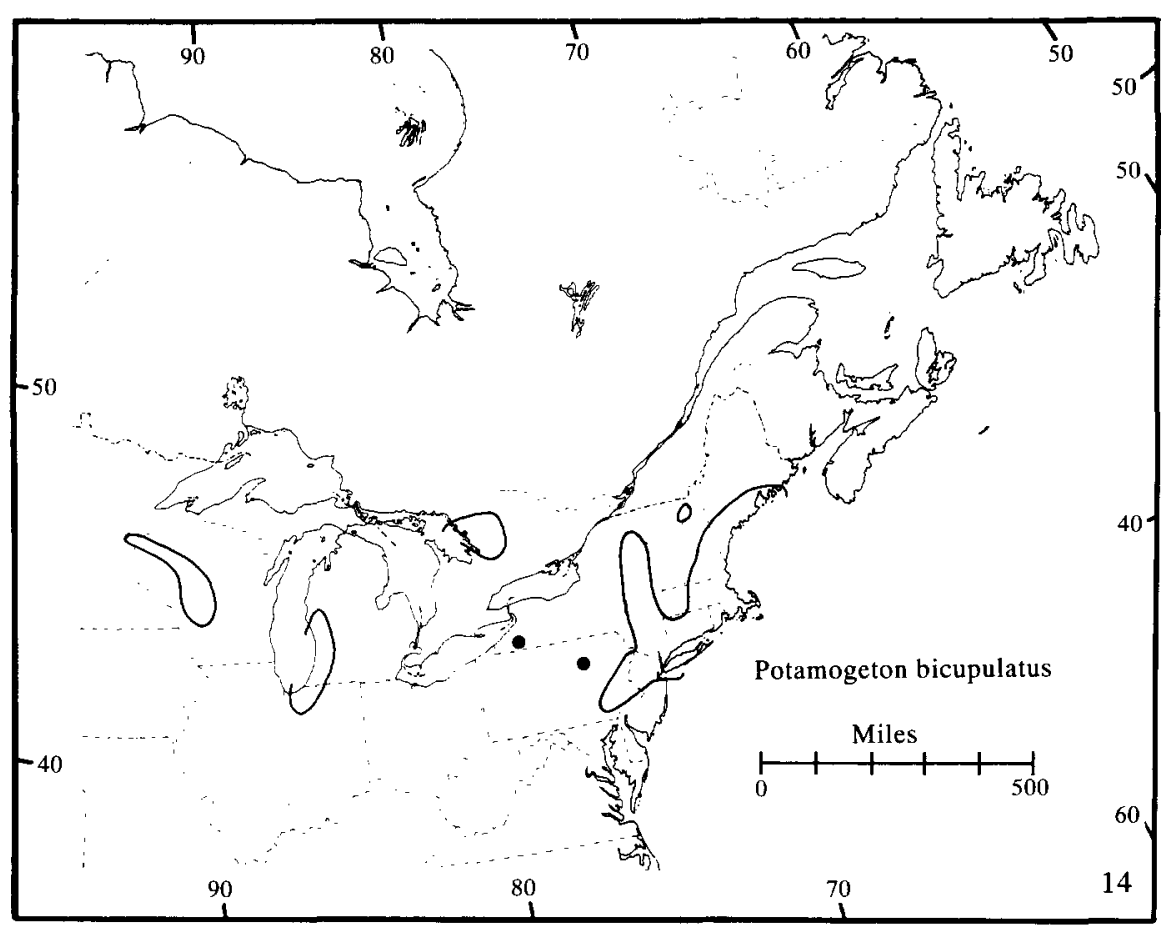

Fig. 14. Distribution of Potamogeton bicupulatus. Based on Reznicek and Bobbette (1976), supplemented by specimens in MICH and records in Hellquist and Crow (1980), New York Flora Association (1990), and Wherry et al. (1979).

the Great Lakes region they are distributed more or less discontinuously and are most frequent in the areas noted for concentrations of coastal plain disjuncts. These species are certainly of coastal plain affinity.

There is also a continuum between northeastern species disjunct to the Great Lakes region, such as Gratiola aurea, Juncus militaris, and Potamogeton bicupulatus, and northeastern species ranging more or less continuously inland to the Great Lakes region, such as Elatine minima, Potamogeton oakesianus, and Scirpus torreyi. As well, there is a continuum between strictly northern species and species more widespread on the coastal plain. Some species, such as Nymphoides cordata occur irregularly as far south as the Gulf coastal plain (Radford et al., 1964; Jones \& Coile, 1988), and could just as well be considered coastal plain species, in spite of their prominence in the north.

Unless a published dot distribution map is available, determining the precise range of a species can be very difficult, especially determining whether an actual disjunction occurs within its range. Most published descriptions of species' ranges are very general. Thus, the distribution of Polygonum careyi given in Fernald (1950) is Maine to Ontario, south to southern New England, Delaware, Pennsylvania, northern Indiana, Wisconsin, and Minnesota. Though technically nearly correct, examination of Fig. 13 shows how little information that description of range contains. The present list, while representing a refinement of Peattie's, must, therefore, also be considered only an approximation. In addition, with further botanical work more species disjunct from the coastal plain will likely be found in the Great Lakes region. Nevertheless, the relative species richness of the different areas and the areas with concentrations of species are likely to remain un- changed, even with the discovery of more species or adoption of somewhat differing definitions of coastal plain disjuncts.

Examination of the species list in Table 1 discloses interesting trends. First, all but two of the species are herbs, and a substantial number are annuals or facultative annuals. Second, nearly half are graminoid, with 21 species belonging to the Cyperaceae and Poaceae alone and the Iridaceae, Isoetaceae, Juncaceae, and Xyridaceae contributing seven more. These trends are undoubtedly related to the oligotrophic wetland habitat of these species. The woody Myrica pensylvanica is somewhat anomalous both in distribution and habitat. It is confined to the Lake Erie region (Little, 1977) and is a generalized successional species of open, sandy or peaty soils. Unlike some categories of disjuncts in the Great Lakes region, for example western species (Marquis \& Voss, 1981), there is no doubt that all these species are native.

\section{HABITATS AND ABUNDANCE OF SPECIES}

Habitats of coastal plain disjuncts have been extensively studied in the Georgian Bay region by Keddy (1981, 1982, 1983, 1985), Keddy and Reznicek (1982), Sharp and Keddy (1985), and Wilson, et al. (1985). Descriptive information is available widely in floras covering the other areas, especially Voss $(1972,1985)$ and Swink and Wilhelm (1979). Thus, only a very brief summary is given here. The great majority of coastal plain disjuncts occur on sandy or gravelly shores of shallow, small, soft-water ponds and lakes with fluctuating water levels, or sometimes in low, sandy, periodically flooded swales. In these habitats, coastal plain species appear only during years of low water levels, when extensive 
Table 1. Distribution of coastal plain disjuncts in the Great Lakes region

\begin{tabular}{|c|c|c|c|c|c|c|c|c|}
\hline Species & $\begin{array}{l}\text { Distribution } \\
\text { code }^{a}\end{array}$ & $\begin{array}{l}\text { SW Michigan, } \\
\text { NW Indiana }\end{array}$ & $\begin{array}{l}\text { SE Georgian } \\
\text { Bay, Ontario }\end{array}$ & Wisconsin & $\begin{array}{l}\text { Lake } \\
\text { Erie }\end{array}$ & $\begin{array}{l}\text { Lake Ontario, } \\
\text { New York }\end{array}$ & $\begin{array}{l}\text { North-central } \\
\text { Illinois }\end{array}$ & $\begin{array}{l}\text { Northern } \\
\text { Michigan }\end{array}$ \\
\hline Aristidia tuberculosa & W & $\mathrm{X}$ & - & $\mathrm{X}$ & - & - & $\mathrm{X}$ & - \\
\hline Bartonia paniculata & W & - & $\mathrm{X}$ & - & - & - & - & $X$ \\
\hline Carex longii & W & $\mathrm{X}$ & - & - & $\mathrm{X}$ & $\mathrm{X}$ & - & - \\
\hline Carex louisianica & W & - & - & - & $\mathrm{X}$ & - & - & - \\
\hline Carex mitchelliana & W & - & - & - & $X$ & - & - & - \\
\hline Cyperus dentatus & $\mathrm{N}$ & $\mathrm{X}$ & - & - & - & - & - & - \\
\hline Dryopteris celsa & W & $\mathrm{X}$ & - & - & $\mathrm{X}$ & - & - & - \\
\hline Echinodorus parvulus & $\mathrm{R}$ & $\mathrm{X}$ & - & - & - & - & $\mathrm{X}$ & - \\
\hline Eleocharis equisetoides & W & $\mathrm{X}$ & - & $\mathrm{X}$ & $\mathrm{X}$ & $\mathrm{X}$ & - & - \\
\hline Eleocharis melanocarpa & $\mathrm{R}$ & $\mathrm{X}$ & $\ldots$ & - & - & - & - & - \\
\hline Eleocharis microcarpa & $\mathrm{R}$ & $\mathrm{X}$ & - & - & - & - & - & - \\
\hline Eleocharis tricostata & $\mathbf{R}$ & $\mathrm{X}$ & - & & - & - & - & - \\
\hline Euthamia tenuifolia & W & $\mathrm{X}$ & 一 & - & - & - & - & - \\
\hline Fuirena pumila & $\mathbf{R}$ & $\mathrm{X}$ & - & $\mathrm{X}$ & $\mathrm{X}$ & - & - & - \\
\hline Gratiola aurea & $\mathrm{N}$ & - & $\mathrm{X}$ & $\mathrm{X}$ & - & - & - & $\mathrm{X}$ \\
\hline Hottonia inflata & W & - & - & - & $\mathrm{X}$ & - & - & - \\
\hline Hydrocotyle umbellata & W & $\mathrm{X}$ & - & - & $X$ & - & - & - \\
\hline Hypericum adpressum & $\mathbf{R}$ & $\mathrm{X}$ & - & - & - & - & - & - \\
\hline Isoëtes engelmannii & W & $\mathrm{X}$ & $\mathrm{X}$ & - & $\ldots$ & $\mathrm{X}$ & - & - \\
\hline Isoëtes tuckermanii & $\mathrm{N}$ & - & $\mathrm{X}$ & - & - & & - & - \\
\hline Juncus militaris & $\mathrm{N}$ & $\mathrm{X}$ & $\mathrm{X}$ & - & - & $\ldots$ & - & $\mathrm{X}$ \\
\hline Juncus scirpoides & W & $\mathrm{X}$ & - & - & - & - & $X$ & - \\
\hline Lechea pulchella & W & $\mathrm{X}$ & - & - & $\mathrm{X}$ & - & $\mathrm{X}$ & - \\
\hline Limnobium spongia & W & $X^{n}$ & - & - & - & $\mathrm{X}$ & - & - \\
\hline Linum striatum & W & $\mathrm{X}$ & $\mathrm{X}$ & - & $\mathrm{X}$ & - & - & - \\
\hline Lipocarpha maculata & $\mathbf{R}$ & - & - & - & - & - & $\mathrm{X}$ & - \\
\hline Ludwigia sphaerocarpa & $\mathbf{R}$ & $\mathrm{X}$ & - & - & - & - & - & - \\
\hline Lycopodium appressum & W & $\mathrm{X}$ & - & - & $\mathrm{X}$ & - & - & - \\
\hline Lycopus amplectens & $\mathbf{R}$ & $\mathrm{X}$ & - & - & - & - & $\mathrm{X}$ & $\ldots$ \\
\hline Lygodium palmatum & $\mathrm{W}$ & $\mathrm{X}$ & - & - & - & - & - & - \\
\hline Mikania scandens & W & $\mathrm{X}$ & - & - & $\mathbf{X}$ & $\mathrm{X}$ & - & - \\
\hline Myrica pensylvanica & $\mathrm{N}$ & 一 & - & - & $\mathrm{X}$ & - & - & - \\
\hline Nymphoides cordata & $\mathrm{N}$ & - & $\mathrm{X}$ & $\mathrm{X}$ & - & - & - & - \\
\hline Panicum longifolium & $\mathbf{R}$ & $\mathbf{X}$ & - & - & - & - & $\mathrm{X}$ & - \\
\hline Panicum meridionale & W & $\mathrm{X}$ & - & $\mathrm{X}$ & $\mathrm{X}$ & $\mathrm{X}$ & - & $\mathrm{X}$ \\
\hline Panicum spretum & $\mathbf{R}$ & $\mathrm{X}$ & $\mathrm{X}$ & - & $X$ & $\mathrm{X}$ & - & $\mathrm{X}$ \\
\hline Panicum verrucosum & $\mathrm{R}$ & $\mathrm{X}$ & - & - & - & - & - & - \\
\hline Polygala cruciata & W & $\mathrm{X}$ & - & $\mathrm{X}$ & $\mathrm{X}$ & - & $\mathrm{X}$ & - \\
\hline Polygonum careyi & $\mathrm{N}$ & $\mathrm{X}$ & $\mathrm{X}$ & $X$ & $\mathrm{X}$ & - & - & $\mathrm{X}$ \\
\hline Potamogeton bicupulatus & $\mathrm{N}$ & $\mathrm{X}$ & $\mathrm{X}$ & $\mathrm{X}$ & - & - & - & - \\
\hline Potamogeton confervoides & $\mathrm{N}$ & - & $\mathrm{X}$ & $\mathrm{X}$ & - & - & - & $\mathrm{X}$ \\
\hline Potamogeton pulcher & W & $\mathrm{X}$ & - & - & $\mathrm{X}$ & 一 & - & $\mathrm{X}$ \\
\hline Proserpinaca pectinata & $\mathbf{R}$ & $\mathrm{X}$ & - & - & - & - & $\ldots$ & - \\
\hline Psilocarya nitens & $\mathbf{R}$ & $\mathrm{X}$ & - & - & - & - & - & - \\
\hline Psilocarya scirpoides & $\mathbf{R}$ & $\mathrm{X}$ & - & $\mathrm{X}$ & $\mathrm{X}$ & - & - & $\mathrm{X}$ \\
\hline Rhexia mariana & W & $\mathrm{X}$ & - & - & - & - & $\mathrm{X}$ & - \\
\hline Rhexia virginica & W & $\mathrm{X}$ & $\mathrm{X}$ & $\mathrm{X}$ & $\mathrm{X}$ & $\mathrm{X}$ & $\mathrm{X}$ & - \\
\hline Rhynchosphora macrostac & chya $\mathrm{W}$ & $\mathrm{X}$ & - & - & - & $\mathrm{X}$ & - & - \\
\hline Sabatia campanulata & W & $\mathrm{X}$ & - & - & - & - & - & - \\
\hline Scleria muhlenbergii & $\mathbf{R}$ & $\mathrm{X}$ & - & - & - & - & - & - \\
\hline Scleria reticularis & $\mathrm{R}$ & $\mathrm{X}$ & - & $\mathrm{X}$ & - & - & $\mathrm{X}$ & - \\
\hline Sisyrinchium atlanticum & $\mathbf{R}$ & $\mathrm{X}$ & - & - & $\mathrm{X}$ & - & - & - \\
\hline Stachys hyssopifolia & W & $\mathrm{X}$ & - & $\mathrm{X}$ & - & - & - & $\mathrm{X}$ \\
\hline Stipa avenacea & W & $\mathrm{X}$ & - & - & $\mathrm{X}$ & - & - & - \\
\hline Styrax americana & W & $\mathrm{X}$ & - & - & - & - & - & - \\
\hline Thelypteris simulata & $\mathbf{N}$ & - & - & $\mathbf{X}$ & - & - & - & - \\
\hline Utricularia geminiscapa & $\mathbf{N}$ & $\mathrm{X}$ & $\mathrm{X}$ & $\mathrm{X}$ & - & - & - & $\mathrm{X}$ \\
\hline Utricularia radiata & $\mathbf{R}$ & $X$ & - & - & - & - & - & - \\
\hline Utricularia subulata & W & $\mathrm{X}$ & - & - & - & - & - & - \\
\hline Woodwardia areolata & W & $\mathrm{X}$ & - & - & - & - & - & - \\
\hline Xyris difformis & $\mathrm{R}$ & $\mathrm{X}$ & $\mathrm{X}$ & - & $\mathrm{X}$ & $\mathrm{X}$ & - & $\mathrm{X}$ \\
\hline Xyris torta & W & $\mathrm{X}$ & - & $\mathrm{X}$ & $\mathrm{X}$ & $X$ & $x$ & - \\
\hline
\end{tabular}

${ }^{a}$ Overall distribution widespread (W), restricted to coastal plain $(\mathrm{R})$, or northern $(\mathrm{N})$ (see text).

${ }^{b}$ This record is evidently not supported by a specimen (Catling \& Dore, 1982; Deam, 1940).

${ }^{c}$ This record is evidently not supported by a specimen (Soper, 1962). 
areas of suitable habitat are exposed. During high water years, these species survive mostly as seeds in the soil under the water. The relationship between fluctuating water levels, seed banks, and the occurrence of coastal plain species has been documented for Matchedash Lake, Ontario by Keddy and Reznicek (1982) and Nicholson and Keddy (1983). A few coastal plain species, including Gratiola aurea, Hydrocotyle umbellata and Juncus militaris, have aquatic morphs and survive high water as adult plants.

Some species, notably Bartonia paniculata and Xyris difformis, frequently occur in bogs, and a few species, including Eleocharis equisetoides, Hottonia inflata, Isoëtes spp., Limnobium spongia, Nymphoides cordata, Potamogeton spp. and Utricularia geminiscapa, are aquatic. The four fern disjuncts, Dryopteris celsa, Lygodium palmatum, Thelypteris simulata and Woodwardia areolata, and the shrub Styrax americana are unique in being swamp forest species. Coastal plain disjuncts may occupy the entire moisture gradient from the driest upper margins of emergent lake and pond shores to shallow water, but few are obligate dryland species. In the areas where coastal plain disjuncts are frequent and natural stands occur nearby, man-made habitats, such as sandy borrow pits scraped to the water table, cleared wet, sandy fields, or even shallow ditches, may offer suitable habitats.

Almost all coastal plain disjunct habitats in the Great Lakes region are located on sand deposits associated with the drying beds and fossil shorelines of postglacial lakes or drainage channels associated with those lakes. However, coastal plain species are scarce on the present day shores of the Great Lakes.

While many coastal plain disjuncts occur scattered in a matrix of more widespread species of similar ecology, others may be abundant and some even the major dominants under appropriate conditions. Species especially capable of dominating communities are Eleocharis melanocarpa, Euthamia tenuifolia, Juncus militaris, Panicum verrucosum, Rhynchospora macrostachya and Stachys hyssopifolia. All but the Panicum are perennials.

Species vary tremendously in frequency of appearance. Some, such as Euthamia tenuifolia, Rhexia spp. and many other of the perennials, appear at the same site almost every year, though sometimes varying widely in abundance. Others appear sporadically, but with only short intervals of absence. Still others appear very irregularly with long intervals between the few observations. The most extreme example of sporadic appearance of a disjunct in the Great Lakes region is Echinodorus parvulus, which was first collected in Michigan (the type locality) in 1837 and then not until 1989, when it was found again, albeit at a site about $100 \mathrm{~km}$ from the original collection. Obviously, it is difficult to state categorically that a seed-banking species is extirpated in the Great Lakes region. Only two species in Table 1 have not been collected in the Great Lakes region since the turn of the century. Limnobium spongia was last collected in the Great Lakes region in 1828 (Catling \& Dore, 1982), although a record from Lake County,
Indiana, apparently not supported by a specimen (Deam, 1940), dates from 1874. The other species is Psilocarya nitens, last collected in 1899 in Porter County, Indiana (Swink \& Wilhelm, 1979).

\section{PHYTOGEOGRAPHY}

Recent authors discussing coastal plain disjuncts in the Great Lakes region have usually concluded simply that they migrated into the Great Lakes area near the end of the last ice age. Peattie (1922), however, suggested that these species migrated from the coastal plain as a community in bands of suitable habitat along the shores of the postglacial Hudson-Mohawk drainage through New York. Dispersal within the Great Lakes region was along the shores of the postglacial Great Lakes and through postglacial connecting drainages, finally to what is now Lake Michigan via the Grand River outlet. Peattie also suggested that a few species could have reached sites in Illinois and Indiana by way of the postglacial Mississippi drainage, the other postglacial outlet to the south. Peattie preferred the northeastern route, because wide ranging coastal plain species occurring no farther north than Delaware normally were not disjunct to the Great Lakes region, even though they may occur northward in the Mississippi embayment. McLaughlin (1932) essentially followed Peattie's ideas, although he also tentatively suggested an additional northern route via the postglacial Ottawa River drainage. Hermann (1936), commenting on the discovery of Juncus militaris in Michigan, also supported a migration route for coastal plain species 'along the shore of the glacial lakes and their Hudson Valley outlet...'.

A number of objections can be raised to Peattie's hypothesis, the most severe of which is that the connections he proposes did not exist contemporaneously (Hough, 1958). Also, even if we accept McLaughlin's (1932) assertions that upstream travel by floating propagules is feasible, most of the species do not now occur on riverbanks or the Great Lakes shores, and there is no reason to suppose that they did so in the recent past. If the species did occur on the shores of rivers and lakes in the past, it is still impossible, given the topographical and geomorphological diversity of the region, for a continuous band of suitable habitat to have extended from the Great Lakes to the coastal plain. Thus, even Peattie's hypothesis requires moderate distance dispersal. The species must therefore also have migrated individually, each at its own rate, and reassembled into an integrated community after dispersal. Furthermore, a few disjuncts, such as Hottonia inflata or Myrica pensylvanica, are not associated with postglacial drainage channels.

Both Peattie (1922) and McLaughlin (1932) strenuously rejected accumulation of species richness by long distance dispersal as a viable alternative hypothesis. Peattie commented that it is obvious that this remarkable distribution is not to be accounted for by that stock method-a most overworked and uncritical methodof dispersal by birds...'. However, no reasons, obvious 
or not, were presented for discarding this hypothesis. In spite of the undeniable efficiency of birds as dispersers, there are, however, difficulties with random, long distance dispersal by birds as the sole factor responsible for these disjunctions. Even within the Great Lakes region, seemingly suitable areas of sandplains with small lakes whose water levels fluctuate have no representation of coastal plain species. Examples include areas of the jack pine Pinus banksiana plains of central lower Michigan and Canadian Shield lakes in southern Ontario beyond those in the southeastern Georgian Bay region. A corollary to the above observation is the highly suggestive positive correlation between the areas with coastal plain disjuncts in the Great Lakes region and the termini of postglacial drainages, a correlation which initially prompted Peattie's hypothesis. As well, the ponds, small lakes, and swales that provide habitat for these species present very tiny targets for dispersal, and yet some of these small sites are rich in coastal plain disjunct species.

Nevertheless, however strong the objections to long distance dispersal may be, there can hardly be any doubt that some dispersal agent, probably birds, must have played a role in the dispersal of these species. At least some of the small swales and ponds where these species occur were never connected to any other ponds nor were ever parts of larger water bodies. Even within the Great Lakes region, some sites for these disjuncts were never connected to the postglacial lakes or any drainage outlets. The scattered, isolated colonies of these species, even in geologically old areas such as the southern Appalachian Mountains or the Ozarks, are especially prominent in species such as Echinodorus parvulus, Scleria reticularis and Xyris difformis (Figs 9-11). While some authors have argued that the entire, rich coastal plain flora evolved in scattered mountain wetlands (e.g. Fernald, 1937; Fassett, 1955), a more parsimonius explanation is simply that long distance dispersal has occurred, especially given the geological time scale involved. In fact, the very same habitats in the Great Lakes region that harbor coastal plain disjuncts also harbor a very few primarily western disjunct pond shore species, including Eleocharis atropurpurea, Hemicarpha drummondii, and Scirpus hallii.

An hypothesis accounting for the occurrence of coastal plain species in the Great Lakes region must integrate the two somewhat conflicting aspects of these species: their demonstrable dispersability and their restriction to specific areas associated with postglacial lakes and drainages even though apparently suitable habitats are more widespread. These can be best reconciled by hypothesizing that migration of these disjuncts into the Great Lakes region probably occurred mostly by short- to moderate-distance dispersal, probably mediated by birds, into discrete areas of suitable habitat existing along major postglacial drainages. The two major drainage outlets to the south also reached the coastal plain at its two closest approaches to the Great Lakes, thus minimizing the dispersal distances in this way as well.
The major dispersal events into the Great Lakes region at the termini of these outlets probably occurred during periods of drying of the landscape, when the areas that are now essentially dry glacial lakebeds were fragmented into dissected, but perhaps more or less interconnected, shallow lakes separate from the main bodies of the postglacial Great Lakes. Then, the extent of emergent shoreline would probably be at its greatest and the target size for dispersal the largest. Easy dispersal throughout the local area would also be possible and might be responsible for the local concentrations noted in Fig. 1. This stage probably corresponded to periods of drying of the outlets, thus also maximizing availability of habitat along the outlets. The end of the Lake Algonquin stage was proposed by Keddy (1981) as a time for the entry of species into the Georgian Bay region. This certainly was a time of shrinkage of the postglacial Great Lakes, and may well be correct. However, sites elsewhere in the Great Lakes region are associated with beaches and lake bottoms of other stages of the Great Lakes and must have had a different timing. At present, with their habitats mostly small and isolated, immigration of additional species into the area and local dispersal of species already there are probably minimal.

The richness of the sites near the southern end of Lake Michigan in southwestern Michigan and adjacent Indiana suggests that many, if not most, species probably utilized areas of suitable habitat in the extensive tracts of sand deposits formed along postglacial Mississippi and Illinois River channels. Certain local areas in northcentral Illinois actually have significant concentrations of coastal plain species (Table 1, also Winterringer, 1959). The primary source of coastal plain disjuncts would thus be the Gulf coastal plain. Species such as Lycopus amplectens, which occur in north-central Illinois and northern Indiana, but are essentially absent from the Gulf coastal plain (Fig. 12), nevertheless remain puzzling.

However, no northern species occur in the northcentral Illinois sites. In fact, there are no species known to be in common between northern Michigan and north-central Illinois. As well, most species occurring in northern Michigan also occur eastward in the Georgian Bay region of Ontario and in the case of Bartonia paniculata and Gratiola aurea occur nowhere else (except for Gratiola in adjacent northern Wisconsin). These species must have dispersed from the east, perhaps through patches of suitable habitat along the HudsonMohawk drainage. Certainly, the species occurring near the east end of Lake Ontario in New York came from the east. Some disjunct species present in the Lake Erie region and nowhere else, e.g. Carex mitchelliana, Hottonia inflata and Myrica pensylvanica, are not associated with postglacial drainage outlets and presumably arrived by long distance dispersal into suitable habitats.

\section{CONSERVATION PROBLEMS}

Coastal plain disjuncts are well represented on rare plants lists and lists of legally protected species in all the 
states where they occur, as well as Ontario. Conservation of the coastal plain flora in the Great Lakes region is an important issue for this reason and because some of the long-isolated disjunct populations may represent unique genotypes. The limited areas of vegetation with coastal plain flora in the Great Lakes region face conservation problems similar to other shoreline wetland floras, including recreational development, off road vehicle traffic, drainage, dredging, elimination of natural water level fluctuations, and eutrophication. Since sites for coastal plain species frequently occupy small areas of shoreline on otherwise more or less developed lakes, control over hydrological alterations, especially stabilization of water levels, is especially difficult. A special difficulty facing sites for coastal plain disjuncts is that a great many of the sites are small, often below the size limits above which wetland development is regulated by federal, state and municipal laws, leaving these tiny sites unusually vulnerable.

Two additional difficulties complicate conservation efforts aimed at the coastal plain flora and are worthy of special mention. The first is that the the plants treated here are all disjuncts, many of them rare. In common with all rare disjunct species, if a local population should die out for any reason, there may not be a seed source close enough to make natural re-establishment of the population a reasonable probability. The second is the irregular appearance of these species at many of their Great Lakes region sites, most of the species appearing primarily during years of low water levels. Some species evidently have even more specific requirements, as they do not appear in all low water years. This obviously greatly complicates surveys, monitoring, and prioritization of sites for conservation. Not observing a plant at a site_-even for a centurydoes not necessarily mean it is extirpated.

More than most types of sites, survey and monitoring work must be conducted over a longer term than one season or one visit. Although ecological parameters can be used to prioritize sites in the same way as other kinds of plant communities, floristic diversity parameters can be applied fairly only if surveys have encountered both high and low water years or if historical data are available.

\section{ACKNOWLEDGEMENTS}

I thank Ted Cochrane and Hugh Iltis for their hospitality during my visit to see Wisconsin sites of these coastal plain disjuncts, discussions of phytogeography, comments on this manuscript, and for providing herbarium records from WIS. Mike Penskar and Dan Brunton also made many useful comments on this manuscript. Bob Kral very kindly provided data to supplement the southeastern United States distributions for the species mapped in Figs 4-12 and Dan Brunton helped with Canadian records. An unpublished report on the coastal plain flora of the Great Lakes region prepared by Bill Brodowicz for the Michigan Natural Features Inventory provided much useful information and food for thought. I also thank my wife Susan, who edited and typed Table 1 and the references and did the final copy for the figures.

\section{REFERENCES}

Cain, S.A. (1944). Foundations of Plant Geography. Harper \& Brothers, New York \& London.

Catling, P.M. \& Dore, W.G. (1982). Status and identification of Hydrocharis morsus-ranae and Limnobium spongia (Hydrocharitaceae) in northeastern North America. Rhodora, 84, 523-45.

Coffin, B. \& Pfannmuller, L. (eds) (1988). Minnesota's Endangered Flora and Fauna. University of Minnesota Press, Minneapolis.

Deam, C.C. (1940). Flora of Indiana. Wm. B. Burford, Indianapolis.

Easterly, N.W. (1979). Rare and infrequent plant species in the oak openings of northwestern Ohio. Ohio J. Sci., 79(2), $51-8$.

Fairey, J.E., III. (1967). The genus Scleria in the southeastern United States. Castanea, 32(1), 37-71.

Fassett, N.C. (1932). Preliminary reports on the flora of Wisconsin, XVI. Xyridales. Trans. Wis. Acad. Sci., 27, 227-30.

Fassett, N.C. (1955). Echinodorus in the American tropics. Rhodora, 57, 133-60, 174-212.

Fernald, M.L. (1937). Local plants of the inner coastal plain of southeastern Virginia. Rhodora, 39, 321-66, 379-415, 433-59, 465-91.

Fernald, M.L. (1942). Misinterpretation of Atlantic coastal plain species. Rhodora, 44, 238-48.

Fernald, M.L. (1950). Gray's Manual of Botany, 8th edn. American Book Co., New York.

Gleason, H.A. \& Cronquist, A. (1991). Manual of Vascular Plants of Northeastern United States and Adjacent Canada. New York Botanical Garden, New York.

Harper, R.M. (1905). Coastal plain plants in New England. Rhodora, 7, 69-80.

Harvill, A.M., Jr, Bradley, T.R., Stevens, C.E., Weiboldt, T.F., Ware, D.M.E. \& Ogle, D.W. (1986). Atlas of the Virginia Flora, 2nd edn. Virginia Botanical Associates, Farmville, Virginia.

Hellquist, C.B. \& Crow, G.E. (1980). Aquatic vascular plants of New England, Part 1. Zosteraceae, Potamogetonaceae, Zannichelliaceae, Najadaceae. New Hampshire Agric. Exp. Stn Bull, No. 515.

Hellquist, C.B. \& Crow. G.E. (1982). Aquatic vascular plants of New England, Part 5. Araceae, Lemnaceae, Xyridaceae, Eriocaulaceae, and Pontederiaceae. New Hampshire Agric. Exp. Stn Bull., No. 523.

Henderson, N.C. (1962). A taxonomic revision of the genus Lycopus (Labiatae). Amer. Midl. Nat., 68(1), 95-138.

Hermann, F.J. (1936). Notes on the flora of Michigan-I. Rhodora, 38, 362-7.

Hinds, H.R. (1986). Flora of New Brunswick. Primrose Press, Fredricton, New Brunswick.

Holmgren, P.K., Holmgren, N.H. \& Barnett, L.C. (1990). Index Herbariorum. Part I. Regnum Vegetabile, Vol. 120. New York Botanical Garden, New York.

Hough, J.L. (1958). Geology of the Great Lakes. University of Illinois Press, Urbana, Illinois.

Jones, S.B. \& Coile, N.C. (1988). The Distribution of the Vascular Flora of Georgia. University of Georgia, Athens, Georgia.

Keddy, C.J. \& Sharp, M.J. (1989). Atlantic Coastal Plain Flora Conservation in Ontario. World Wildlife Fund, Ottawa.

Keddy, P.A. (1981). Vegetation with Atlantic coastal plain affinities in Axe Lake, near Georgian Bay, Ontario. Can. Fieid-Nat., 95, 241-8. 
Keddy, P.A. (1982). Quantifying within-lake gradients of wave energy: Interrelationships of wave energy, substrate particle size, and shoreline plants in Axe Lake, Ontario. Aquat. Bot., 14, 41-58.

Keddy, P.A. (1983). Shoreline vegetation in Axe Lake, Ontario: Effects of exposure on zonation patterns. Ecology, 64, 331-44.

Keddy, P.A. (1985). Wave disturbance on lakeshores and the within-lake distribution of Ontario's coastal plain flora. Can. J. Bot., 63, 656-69.

Keddy, P.A. \& Reznicek, A.A. (1982). The role of seedbanks in the persistence of Ontario's coastal plain flora. Amer. $J$. Bot., 69, 13-22.

Kral, R. (1966). Xyris (Xyridaceae) of the continental United States and Canada. Sida, 2(3), 177-260.

Kral, R. (1978). A synopsis of Fuirena (Cyperaceae) for the Americas north of South America. Sida, 7(4), 309-54.

Kral, R. \& Bostick, P.E. (1969). The genus Rhexia (Melastomataceae). Sida, 3(6), 387-440.

Little, E.L., Jr (1977). Atlas of the United States Trees. Vol. 4. Minor Eastern Hardwoods. USDA Misc. Publs, No. 1342.

Marquis, R.J. \& Voss, E.G. (1981). Distributions of some western North American plants disjunct in the Great Lakes region. Mich. Bot., 20, 53-82.

McCance, R.M., Jr \& Burns, J.F. (1984). Ohio Endangered and Threatened Vascular Plants. Abstracts of State-listed Taxa. Department of Natural Resources, Columbus.

McLaughlin, W.T. (1932). Atlantic coastal plain plants in the sand barrens of Wisconsin. Ecol. Monogr., 2, 335-83.

Mohlenbrock, R.H. \& Ladd, D.M. (1978). Distribution of Illinois Vascular Plants. Southern Illinois University Press, Carbondale \& Edwardsville, Illinois.

New York Flora Association (1990). Preliminary Vouchered Atlas of New York State Flora, 1st edn. Albany, New York.

Vicholson, A. \& Keddy, P.A. (1983). Depth profile of a shoreline seedbank in Matchedash Lake, Ontario. Can. $J$. Bot., 61, 3293-6.

Orzell, S.L. \& Bridges, E.L. (1987). Further additions and noteworthy collections in the flora of Arkansas, with historical, ecological, and phytogeograhical notes. Phytologia, 64(2), 81-164.

Parker, D. (1936). Affinities of the flora of Indiana. Part 1. Amer. Midl. Nat., 17(4), 700-24.

Peattie, D.C. (1922). The Atlantic coastal plain element in the flora of the Great Lakes. Rhodora, 24, 57-70, 80-8.

Peattie, D.C. (1930). Flora of the Indiana Dunes. Field Museum of Natural History, Chicago, Illinois.

Pryer, K.M. (1987). Polygonum careyi Olney. In Atlas of the Rare Vascular Plants of Ontario, Part 4, ed. K.M. Pryer \& G.W. Argus. National Museum of Natural Sciences, Ottawa (unpaginated)

Radford, A.E., Ahles, H.E. \& Bell, C.R. (1964). Manual of the Vascular Flora of the Carolinas. University of North Carolina Press, Chapel Hill, North Carolina.
Randall, D.L. \& Keddy, P.A. (1983). Xyris difformis Chapman. In Atlas of the Rare Vascular Plants of Ontario, Part 2, ed. G.W. Argus \& D.J. White. National Museum of Natural Sciences, Ottawa (unpaginated).

Reznicek, A.A. (1984). Dichanthelium spretum (Schultes) Freckmann. In Atlas of the Rare Vascular Plants of Ontario, Part 3, ed. G.W. Argus \& C.J. Keddy. National Museum of Natural Sciences, Ottawa (unpaginated).

Reznicek, A.A. \& Bobbette, R.S.W. (1976). The taxonomy of Potamogeton subsection hybridi in North America. Rhodora, 78, 650-73.

Reznicek, A.A. \& Catling, P.M. (1984). Notes on Canadian sedges. Can. Field-Nat., 98, 209-14.

Reznicek, A.A. \& Whiting, R.E. (1976). Bartonia (Gentianaceae) in Ontario. Can. Field-Nat., 90, 67-9.

Roland, A.E \& Smith, E.C. (1969). The Flora of Nova Scotia. Nova Scotia Museum, Halifax, Nova Scotia.

Seymour, F.C. (1969). The Flora of New England. Charles E. Tuttle Inc., Tokyo.

Sharp, M.J. \& Keddy, P.A. (1983). Rhexia virginica L. In Atlas of the Rare Vascular Plants of Ontario, Part 2, ed. G.W. Argus \& D.J. White. National Museum of Natural Sciences, Ottawa (unpaginated).

Sharp, M.J. \& Keddy, P.A. (1985). Biomass accumulation by Rhexia virginica and Triadenum fraseri along two lakeshore gradients: A field experiment. Can.. J. Bot., 64, 1806-10.

Smith, E.B. (1988). An Atlas and Annotated List of the Vascular Plants of Arkansas, 2nd Edn. University of Arkansas, Fayetteville.

Soper, J.H. (1962). Some genera of restricted range in the Carolinian flora of Canada. Trans. R. Can. Inst., 34(1), 3-56.

Steyermark, J. (1963). Flora of Missouri. University of Iowa Press, Ames, Iowa.

Svenson, H.K. (1937). Monographic studies in the genus Eleocharis, IV. Rhodora, 39, 210-31, 236-273.

Swink, F. \& Wilhelm, G. (1979). Plants of the Chicago Region. Morton Arboretum, Lisle, Illinois.

Tans, W.E. (1983). Recent Wisconsin records for some interesting vascular plants in the western Great Lakes region-II. Mich. Bot., 22(1), 11-18.

Voss, E.G. (1972). Michigan flora, Part I. Gymnosperms and Monocots. Cranbrook Institute of Science, Bloomfield Hills Bull., No. 55.

Voss, E.G. (1985). Michigan flora, Part II. Dicots (Saururaceae-Cornaceae). Cranbrook Institute of Science, Bloomfield Hills Bull., No. 59.

Wherry, E.T., Fogg, J.M., Jr \& Wahl, H.A. (1979). Atlas of the Flora of Pennsylvania. University of Pennsylvania, Morris Arboretum, Philadelphia.

Wilson, S.D., Keddy, P.A. \& Randall, D.L. (1985). The distribution of Xyris difformis along a gradient of exposure to waves: An experimental study. Can. J. Bot., 63, 1226-30.

Winterringer, G.S. (1959). Notes on Cyperaceae from Illinois. Rhodora, 61, 290-2. 